\title{
Klor u vodi - primjer kemijske ravnoteže i reaktivnosti
}

\section{N. Raos *}

Institut za medicinska istraživanja i medicinu rada, Ksaverska cesta 2, p.p. 291, 10001 Zagreb

\begin{abstract}
Sažetak
Klorna voda nije, jednostavno, otopina klora u vodi, nego složena otopina koja sadrži elementarni klor, $\mathrm{Cl}_{2}(\mathrm{aq})$, klorovodičnu $(\mathrm{HCl})$ i hipoklorastu kiselinu ( $\mathrm{HOCl})$ uz trikloridne ione $\left(\mathrm{Cl}_{3}{ }^{-}\right)$i možebitno zaostalu kuhinjsku sol, NaCl. Sve te komponente stoje u međusobnoj kemijskoj ravnoteži. U radu je opisana kratka povijest kemije i tehnologije klora, prikazane su ravnotežne reakcije u njegovoj vodenoj otopini te primjena $\mathrm{HOCl}$ kao dezinfekcijskog sredstva uz navođenje njezinih kemijskih i fizioloških učinaka. U posljednje je vrijeme razrijeđena klorna voda (50 - 100 ppm) postala popularna kao dezinfekcijsko sredstvo ("elektrokemijski aktivirana voda", ECA, i sl.). lako se ECA jednostavno priprema, elektrolizom razrijeđene vodene otopine $\mathrm{NaCl}$, veliku pozornost treba posvetiti njezinoj čistoći te režimu skladištenja kako bi ostala dugo vremena stabilna.
\end{abstract}

Ključne riječi

Nastava kemije, povijest kemije i kemijske tehnologije, hipoklorasta kiselina, dezinfekcijska sredstva, reakcije klora

\section{Uvod}

Klor je kemijski element koji je dvaput otkriven (tablica 1). Prvi put ga je otkrio 1774. godine švedski kemičar Carl Wilhelm Scheele (1742. - 1786.), reakcijom "crne magnezije" (piroluzita, $\mathrm{MnO}_{2}$ ) sa solnom kiselinom, kao zagušljiv i vrlo reaktivan žutozeleni plin. ${ }^{1}$ Nazvao ga "deflogistonirana solna kiselina" (acidum muriaticum dephlogystorum). Antoine Laurent Lavoisier (1743. - 1794.) smatrao ga je oksidom još neotkrivenog elementa (kojem je nadjenuo ime murium), no svakako radikalom solne kiseline (le radical muriatique). John Dalton (1766. - 1844.) mu 1808. godine pripisuje formulu $\mathrm{HO}_{4}$ (oxymuriatic acid), ${ }^{2}$ a klorovodik također smatra spojem vodika i kisika $\left(\mathrm{HO}_{3}\right)^{* * *}$ Drugi je put klor otkriven 1810. Tada ga je Humphry Davy (1778. - 1829.) prepoznao kao novi kemijski element jer ni nakon mnogo raznovrsnih eksperimenata nije uspio dokazati da "oksirasolna kiselina" sadrži kisik i vodik (vodu)., Dao mu je ime chlorine ili chloric gas, izvodeći ga od grčke riječi $\chi \lambda \omega \rho o ́ \varsigma$ (zelen, zelenkastožut).

Zbog svoje reaktivnosti klor je brzo našao tehnološku primjenu. Godine 1785. Claude Louis Berthollet (1748. - 1822.), nastavljajući Scheeleova israživanja klo-

\section{${ }^{*}$ Dr. sc. Nenad Raos}

e-pošta: raos@imi.hr

** To je bilo sasvim u skladu s ondašnjom teorijom kiselina po kojoj su kiseline bile nužno spojevi s kisikom (odatle i Lavoisierov naziv oxygené

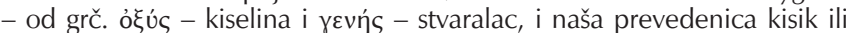
kiselik). Davyjevo prepoznavanje klora kao elementa nije stoga važno samo zbog otkrića još jednog kemijskog elementa nego i zbog rušenja općeprihvaćene teorije da kiseline moraju sadržavati kisik - iako se Davy oprezno ogradio od takvog zaključka ("Should it [chlorine] thereafter be discovered to be compound, and even to contain oxygen, this name can imply no error, and cannot necessarily require a change" ${ }^{\prime 4}$ ).
Tablica 1 - Svojstva plinovitog klora

Table 1 - Properties of chlorine gas

\begin{tabular}{|c|c|}
\hline $\begin{array}{l}\text { Relativna molekulska masa } / \mathrm{g} \mathrm{mol}^{-1} \\
\text { Relative molecular mass } / \mathrm{g} \mathrm{mol}^{-1}\end{array}$ & 70,90 \\
\hline $\begin{array}{l}\text { Talište } /{ }^{\circ} \mathrm{C} \\
\text { Melting point } /{ }^{\circ} \mathrm{C}\end{array}$ & $-101,5$ \\
\hline $\begin{array}{l}\text { Vrelište } /{ }^{\circ} \mathrm{C} \\
\text { Boiling point } /{ }^{\circ} \mathrm{C}\end{array}$ & $-34,04$ \\
\hline $\begin{array}{l}\text { Kritična temperatura } /{ }^{\circ} \mathrm{C} \\
\text { Critical temperature } /{ }^{\circ} \mathrm{C}\end{array}$ & 143,75 \\
\hline $\begin{array}{l}\text { Latentna toplina isparavanja } / \mathrm{kJ} \mathrm{kg}^{-1} \\
\text { Latent heat of evaporation } / \mathrm{kJ} \mathrm{kg}^{-1}\end{array}$ & 288,1 \\
\hline $\begin{array}{l}\text { Gustoća tekućeg klora } / \mathrm{g} \mathrm{cm}^{-3} \\
\text { Density of liquid chlorine } / \mathrm{g} \mathrm{cm}^{-3}\end{array}$ & 1,57 \\
\hline $\begin{array}{l}\text { Toplijivost u vodi }(p=1 \mathrm{~atm}) / \\
m\left(\mathrm{Cl}_{2}\right) / m\left(\mathrm{H}_{2} \mathrm{O}\right) \cdot 100 \\
\text { Water solubility }(p=1 \mathrm{~atm}) / \\
m\left(\mathrm{Cl}_{2}\right) / m\left(\mathrm{H}_{2} \mathrm{O}\right) \cdot 100\end{array}$ & $\begin{array}{l}0,7293\left(20^{\circ} \mathrm{C}\right) \\
0,6413\left(25^{\circ} \mathrm{C}\right)\end{array}$ \\
\hline $\begin{array}{l}\text { Topljivost u vodi }(p=1 \mathrm{~atm}) / V\left(\mathrm{Cl}_{2}\right) / V\left(\mathrm{H}_{2} \mathrm{O}\right) \\
\text { Water solubility }(p=1 \mathrm{~atm}) / V\left(\mathrm{Cl}_{2}\right) / V\left(\mathrm{H}_{2} \mathrm{O}\right)\end{array}$ & $\begin{array}{l}2,299\left(20^{\circ} \mathrm{C}\right) \\
2,019\left(25^{\circ} \mathrm{C}\right)\end{array}$ \\
\hline $\begin{array}{l}\text { Granice eksplozivnosti } / V\left(\mathrm{Cl}_{2}\right) /\left[V\left(\mathrm{Cl}_{2}\right)+V\left(\mathrm{H}_{2}\right)\right] \\
\text { Explosive range } / V\left(\mathrm{Cl}_{2}\right) /\left[V\left(\mathrm{Cl}_{2}\right)+V\left(\mathrm{H}_{2}\right)\right]\end{array}$ & $0,04-0,93$ \\
\hline
\end{tabular}

ra, pokušava njegovu sposobnost obezbojenja biljnih boja iskoristiti za bijeljenje tekstila, no nalazi ga neprikladnim zbog velike reaktivnosti - klor rastače vunu i svilu. Uskoro otkriva da se klor ne otapa samo u vodi - pri čemu nastaje "klorna voda" - nego i u lužini, pa 1789. godine podiže u Javelleu pokraj Pariza tvornicu za proizvodnju "javellske 
vode" (eau de Javelle), tj. vodene otopine kalijeva hipoklorita $(\mathrm{KOCl})$. No 1799. godine engleski kemičar Smithson Tennant (1761. - 1815.) pronalazi da se isto djelovanje na tekstil može postići uvođenjem klora u mnogo jeftiniju kalcijevu lužinu, tj. u gašeno vapno, $\mathrm{Ca}(\mathrm{OH})_{2}$. Tako je dobio klorno vapno, koje, međutim, nije čisti kalcijev hipoklorit, $\mathrm{Ca}(\mathrm{OCl})_{2}$, nego smjesa kalcijeva hipoklorita, klorida i hidroksida. Njegov se sastav može opisati formulom $3 \mathrm{Ca}(\mathrm{OCl}) \mathrm{Cl} \cdot \mathrm{Ca}(\mathrm{OH})_{2} \cdot 5 \mathrm{H}_{2} \mathrm{O}$, no moguće je prirediti klorno vapno i u obliku smjese klorida i hipoklorita, $\mathrm{Ca}(\mathrm{OCl})$ $\mathrm{Cl} \cdot 4 \mathrm{H}_{2} \mathrm{O}$ ili $\mathrm{Ca}(\mathrm{OCl}) \mathrm{Cl}$ (kaporit). Zbog jeftinoće i mogućnosti da se skladišti u krutom stanju, klorno vapno ubrzo je zamijenilo javellsku vodu za bijeljenje tekstila. Danas se, međutim, najviše upotrebljava vodena otopina natrijeva hipoklorita (eau de Labarraque), koja se proizvodi od 1820. godine. Primjenuje se u stomatologiji, a u smjesi s bornom kiselinom rabila se za suzbijanje infekcija rana u Prvom svjetskom ratu (Dakin-Carrelova otopina). Kod nas je poznata pod trgovačkim imenom Varekina ili Varikina.

Klor se isprva proizvodio reakcijom klorovodične kiseline s $\mathrm{MnO}_{2}$, postupkom koji je 1866. usavršio Walter Weldon (1842. - 1885.) tako da je regenerirao nastali $\mathrm{MnCl}_{2}$ grijanjem na zraku (Weldonov postupak). Godine 1872. Henry Deacon (1822. - 1876.) izumio je postupak u kojem se klorovodik oksidira zrakom pri temperaturi $430-440{ }^{\circ} \mathrm{C}$ uz $\mathrm{CuCl}_{2}$ kao katalizator. Danas se klor proizvodi poglavito elektrolizom zasićene otopine natrijeva klorida (da bi se snizila topljivost klora). Pri tome klor nastaje u anodnom, a natrijeva lužina u katodnom prostoru, koji - razumije se - moraju biti odvojeni dijafragmom. Zanimljivo je spomenuti da je nastajanje klora pri elektrolizi vodene otopine natrijeva klorida otkriveno još 1801. Godine 1885. podignuta je u Griesheimu prva tvornica za proizvodnju natrijeve lužine i klora elektrolitičkim postupkom (Griesheimski postupak), pri čemu je kationski prostor od anionskog bio odvojen cementnom dijafragmom (Zementdiaphragma). Na tu je tvornicu uoči Prvoga svjetskog rata otpadala trećina svjetske proizvodnje klora, ${ }^{5}$ plina koji su Nijemci upotrijebili i kao (prvi) bojni otrov (zagušljivac), na bojišnici u Belgiji 22. travnja 1915.

\section{Otapanje klora u vodi}

Otapanje klora u vodi ("nastajanje klorne vode") nije jednostavan proces, poput otapanja kisika ili dušika (tablica 2). Riječ je naime o više procesa; prvi je fizičko otapanje:

$$
\mathrm{Cl}_{2}(\mathrm{~g}) \rightleftharpoons \mathrm{Cl}_{2}(\mathrm{aq})
$$

nakon čega slijedi reakcija s vodom (hidroliza) otopljenog klora:

$$
\mathrm{Cl}_{2}(\mathrm{aq})+\mathrm{H}_{2} \mathrm{O} \rightleftharpoons \mathrm{HOCl}+\mathrm{HCl} .
$$

Obje kiseline, hipoklorasta $(\mathrm{HOCl})$ i klorovodična $(\mathrm{HCl})$ mogu elektrolitički disocirati:

$$
\begin{gathered}
\mathrm{HOCl} \rightleftharpoons \mathrm{H}^{+}+\mathrm{OCl}^{-} \\
\mathrm{HCl} \rightleftharpoons \mathrm{H}^{+}+\mathrm{Cl}^{-} .
\end{gathered}
$$

Klorovodična kiselina je jaka kiselina, pa se može smatrati da je potpuno disocirana. Stoga se jedn. (2) i (4) mogu spojiti u jednu:

$$
\mathrm{Cl}_{2}+\mathrm{H}_{2} \mathrm{O} \rightleftharpoons \mathrm{HOCl}+\mathrm{H}^{+}+\mathrm{Cl}^{-} .
$$

Hipoklorasta kiselina je slaba kiselina, slabija od sumporovodične $\left(\mathrm{H}_{2} \mathrm{~S} \rightarrow \mathrm{H}^{+}+\mathrm{HS}^{-}, \mathrm{pK}_{\mathrm{a}}=7,0\right)$. Njezina konstanta disocijacije,

$$
K_{\mathrm{a}}=\frac{\left[\mathrm{H}^{+}\right]\left[\mathrm{OCl}^{-}\right]}{[\mathrm{HOCl}]},
$$

iznosi oko $10^{-8}\left(\mathrm{p} K_{\mathrm{a}} \approx 8\right)$. Navodim približnu vrijednost zato jer $K_{a}$ ovisi o temperaturi, ali i o uvjetima te metodi mjerenja. Najpouzdanija vrijednost za temperaturu $25{ }^{\circ} \mathrm{C}$ je $K_{\mathrm{a}}=2,9 \cdot 10^{-8} \mathrm{moll}^{-1}\left(\mathrm{p} K_{\mathrm{a}}=7,537\right)$, što je dosta različito od konstanti izmjerenih pri $0{ }^{\circ} \mathrm{C}\left(\mathrm{p} K_{\mathrm{a}}=7,825\right)$ i $35^{\circ} \mathrm{C}$ $\left(\mathrm{p} K_{\mathrm{a}}=7,463\right){ }^{6}$

Za plinove koji kemijski ne reagiraju s otapalom vrijedi Henryjev zakon:

$$
c=\mathrm{k} p,
$$

gdje je $p$ parcijalni tlak plina iznad otopine, $k$ je Henryjeva konstanta, a $c$ ravnotežna koncentracija otopljene tvari (plina). Je li moguće izmjeriti Henryjevu konstantu klora $\left(\mathrm{Cl}_{2}\right)$ unatoč tome što reagira s vodom? Ili, drugim riječima, je li moguće odvojiti proces opisan jedn. (1) od svih drugih procesa?

Odgovor na pitanje je potvrdan. Jasno je naime da će se ravnoteža (jedn. 5) pomicati u lijevo, u smjeru nastajanja klora, ako se klorna voda zakiseli klorovodičnom kiselinom (jedn. 6).

*To je skraćeni oblik pisanja, uobičajen u stručnoj literaturi; korektnije bi bilo pisati $\mathrm{HOCl}+\mathrm{H}_{2} \mathrm{O} \rightleftharpoons \mathrm{H}_{3} \mathrm{O}^{+}+\mathrm{OCl}^{-}$. Formula u uglatoj zagradi, npr. $\left[\mathrm{OCl}^{-}\right]$(jedn. 8), označava ravnotežnu koncentraciju reaktanta. $1 \mathrm{~atm}=1013,25 \mathrm{hPa}$.

Tablica 2 - Konstante ravnoteže za interakcije klora s vodom (ref. 36)

Table 2 - Equilibrium constants for interactions of chlorine with water (Ref. 36)

\begin{tabular}{c|c|c}
\hline $\begin{array}{c}\text { Interakcija } \\
\text { Interaction }\end{array}$ & $\begin{array}{c}\text { Konstanta ravnoteže } \\
\text { Equilibrium constant }\end{array}$ & $\begin{array}{c}\text { Jednadžba } \\
\text { Equation }\end{array}$ \\
\hline $\mathrm{Cl}_{2}(\mathrm{aq}) \rightleftharpoons \mathrm{Cl}_{2}(\mathrm{~g})$ & $10,87 \mathrm{~atm} \mathrm{Imol} \mathrm{mol}^{-1}$ & $(1)$ \\
\hline $\mathrm{HOCl}+\mathrm{H}^{+}+\mathrm{Cl}^{-} \rightleftharpoons \mathrm{Cl}_{2}(\mathrm{aq})+\mathrm{H}_{2} \mathrm{O}$ & $9,6 \cdot 10^{3} \mathrm{I}^{2} \mathrm{~mol}^{-2}$ & $(5)$ \\
\hline $\mathrm{HOCl} \rightleftharpoons \mathrm{H}^{+}+\mathrm{OCl}^{-}$ & $3,1 \cdot 10^{-8} \mathrm{~mol} \mathrm{I}^{-1}(\mathrm{pK}=7,5)$ & $(3)$ \\
\hline $\mathrm{Cl}_{2}(\mathrm{aq})+\mathrm{Cl}^{-} \rightleftharpoons \mathrm{Cl}_{3}{ }^{-}$ & $0,18 \mathrm{~mol}^{-1}$ & $(9)$ \\
\hline
\end{tabular}




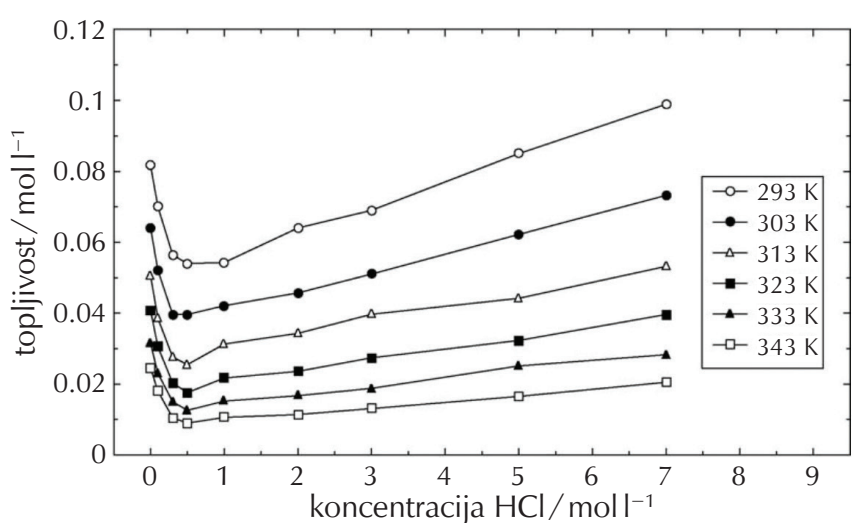

Slika 1 - Ovisnost topljivosti klora o koncentraciji $\mathrm{HCl}$ (ref. 8)

Fig. 1 - Dependence of chlorine gas solubility on $\mathrm{HCl}$ concentration (Ref. 8)

Ta je pojava iskorištena, zakiseljavanjem klorne vode klorovodičnom kiselinom koncentracije $0,096 \mathrm{moll}^{-1}$, da bi se izmjerila Henryjeva konstanta za otapanje klora u vodi. ${ }^{7}$ Ona pri temperaturi od $20^{\circ} \mathrm{C}$ iznosi $\mathrm{k}=0,07369 \mathrm{moll}^{-1} \mathrm{~atm}^{-1}$, što pri atmosferskom tlaku odgovara masenoj koncentraciji klora $\gamma=5,225 \mathrm{gl}^{-1}$. No u vodi se pri toj temperaturi i tlaku otapa više klora $(0,7293$ g na 100 grama otapala, tablica 1), što ukazuje na kemijski proces, naime na hidrolizu $\mathrm{Cl}_{2}(\mathrm{aq})$, (jedn. 2).

Iz jedn. (5) slijedi da topljivost klora u vodi ne smanjuje samo koncentracija iona $\mathrm{H}^{+}$nego i iona $\mathrm{Cl}^{-}$, tj. da se topljivost klora u vodi može smanjiti i dodavanjem klorida (porastom ionske jakosti). Ta je pojava također istražena u spomenutom radu, ${ }^{7}$ a u Uvodu sam već spomenuo da se klor dobiva elektrolizom zasićene otopine $\mathrm{NaCl}$ kako bi mu se smanjila topljivost.

Topljivost klora u vodi je međutim složeniji proces od onoga koji se može opisati jedn. (5), tj. konstantom ravnoteže koja iz nje proizlazi:

$$
K=\frac{\left[\mathrm{H}^{+}\right]\left[\mathrm{Cl}^{-}\right][\mathrm{HOCl}]}{\left[\mathrm{Cl}_{2}\right]},
$$

budući da pri višim koncentracijama $\mathrm{HCl}$ raste topljivost $\mathrm{Cl}_{2}$ (slika 1). To se objašnjava još jednom reakcijom otopljenog klora, ovog puta s kloridnim ionima: ${ }^{8}$

$$
\mathrm{Cl}_{2}(\mathrm{aq})+\mathrm{Cl}^{-} \rightleftharpoons \mathrm{Cl}_{3}^{-},
$$

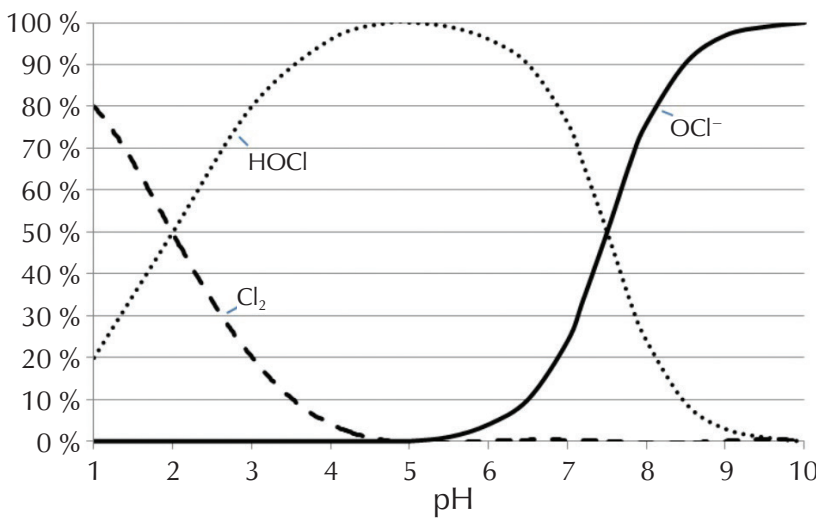

Slika 2 - Ovisnost udjela tri klorne molekulske vrste o vrijednosti pH klorne vode

Fig. 2 - Dependence of the ratio of the three chlorine molecular species on $\mathrm{pH}$ of chlorine water

što je je analogno poznatoj reakciji nastajanja trijodida $\left(\mathrm{I}_{2}+\mathrm{I}^{-} \rightarrow \mathrm{I}_{3}^{-}\right)$. No bez obzira na takve suptilnosti, za klor u njegovoj vodenoj otopini može se reći da postoji u tri "aktivna" (oksidativna) oblika: kao diklor $\left(\mathrm{Cl}_{2}\right)$, kao hipoklorasta kiselina $(\mathrm{HOCl})$ i kao hipokloritni ion $\left(\mathrm{OCl}^{-}\right)$. U jako kiselim otopinama prevladavat će prvi, u slabo kiselim otopinama ( $\mathrm{pH}=4-6)$ drugi, a u lužnatim otopinama treći oblik (slika 2).

\section{Klorna voda kao dezinfekcijsko sredstvo}

U posljednje vrijeme raste popularnost "hipokloraste kiseline $^{\prime \prime *}$ kao sredstva za dezinfekciju. ${ }^{9,10}$ Taj se pripravak pojavljuje pod zvučnim imenima poput "neutral electrolyzed water", "slightly acidic electrolyzed water" (SAE), "electrochemically activated water" (ECA), "electrochemically activated solutions" (ECAS), "super-oxidized water", "slightly acidic hypochlorous acid water" (SAHAW) i slično, te pod više komercijalnih naziva (tablica 3). Takve oto-

\footnotetext{
" lako se često deklarira kao $\mathrm{HOCl}$, klorna voda nije hipoklorasta kiselina iako se regulacijom vrijednosti $\mathrm{pH}$ nastoji da što više aktivnog klora bude u tom obliku. Uz hipoklorastu kiselinu klorna voda sadržava otopljeni $\mathrm{Cl}_{2}$ i $\mathrm{HCl}$ koji stoje u ravnoteži s $\mathrm{HOCl}$ te $\mathrm{NaCl}$ koji nije do kraja razložen elektrolizom. Čista HOCl dobiva se uklanjanjem $\mathrm{HCl}$ (reakcijom s HgO ili $\mathrm{Ag}_{2} \mathrm{O}$ ) te odvajanjem od $\mathrm{NaCl}$ destilacijom pod sniženim tlakom (v. npr. ref. 6). Hipoklorasta kiselina može postojati samo u obliku vodene otopine, jer oduzimanjem vode prelazi u svoj anhidrid, klorov(I) oksid $\left(\mathrm{Cl}_{2} \mathrm{O}\right)$, koji također služi kao dezinfekcijsko sredstvo.
}

Tablica 3 - Komercijalni pripravci razrijeđene klorne vode

Table 3 -Commercial formulations of diluted chlorine water

\begin{tabular}{c|c|c|c|c}
\hline $\begin{array}{c}\text { Ime } \\
\text { Name }\end{array}$ & $w(\mathrm{HOCl}) / \mathrm{ppm}$ & $\mathrm{pH}$ & $\begin{array}{c}\text { Redoks-potencijal }(\mathrm{ORP}) / \mathrm{mV} \\
\text { Redox potential }(\mathrm{ORP}) / \mathrm{mV}\end{array}$ & $\approx 1000$ \\
\hline NVC-101 & 100 & $3,5-4$ & $>950$ & 35,36 \\
\hline Medilox ${ }^{\circledR}$ & $30-50$ & $5,0-6,5$ & $>950$ & 13 \\
\hline Sterilox ${ }^{8}$ & 144 & $5,0-6,5$ & $750-900$ & 29,37 \\
\hline Superoxide water (Tiaano) & $50-200$ & $5,5-7,0$ & 20 \\
\hline
\end{tabular}




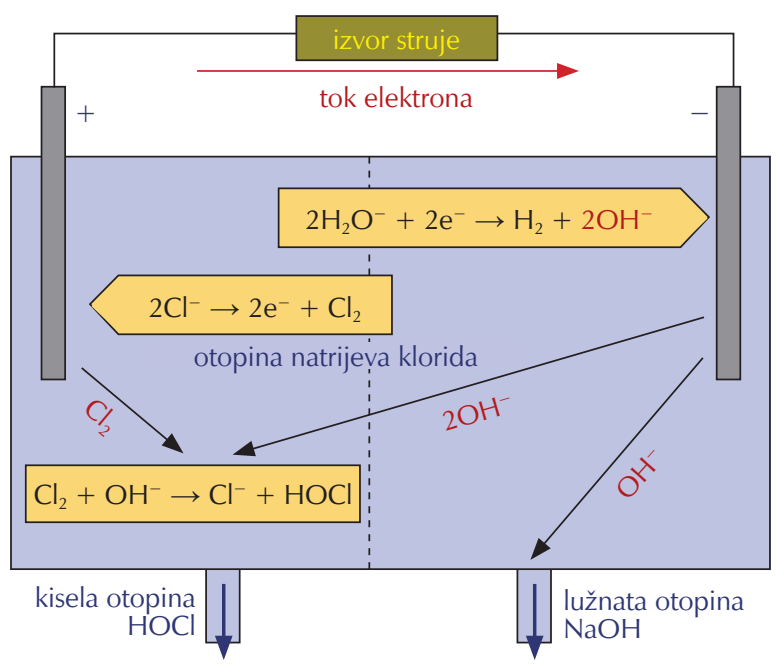

Slika 3 - Shematski prikaz ćelije za elektrolizu vodene otopine $\mathrm{NaCl}$ s dijafragmom

Fig. 3 - Scheme of cell with a diaphragm for electrolysis of $\mathrm{NaCl}$ solution

pine obično sadrže 100 do $200 \mathrm{mgl}^{-1}$ (100 - 200 ppm) aktivnog klora, poglavito u obliku $\mathrm{HOCl}$, blago su kisele $(\mathrm{pH}=2-5)$ te imaju redoks-potencijal (ORP) između $+800 \mathrm{i}+1200 \mathrm{mV} .{ }^{11}$ Priređuju se, kao što im ime sugerira, elektrolizom razrijeđene otopine natrijeva klorida $u$ protočnoj ćeliji s dijafragmom (slike 3 i 4), pa sadržavaju i nešto otopljenog $\mathrm{NaCl}$.

Hipoklorasta kiselina smatra se vrlo djelotvornim dezinfekcijskim sredstvom, posebice protiv virusa, pa i uzročnika bolesti COVID-19. ${ }^{12}$ Velik broj patogenih bakterija (Staphylococcus aureus, Salmonella typhi, Escherichia coli i dr.) te gljivica (Candida albicans) ubija $\mathrm{HOCl}$ koncentracije $30 \mathrm{mgl}^{-1}$ (30 ppm) već nakon 30 s, dok joj za ubijanje sporogene bakterije Bacillus subtilis treba $4 \mathrm{~min}^{13}$ To su stotinjak puta manje koncentracije od onih u kojima se primjenjuje otopina natrijeva hipoklorita u stomatologiji $\left(w=3\right.$ ili 5,25\%), ${ }^{14}$ pa se može očekivati da je citotoksičnost antiseptika baziranog na $\mathrm{HOCl}$ manja od one koja se osniva na $\mathrm{NaOCl} .{ }^{15} \mathrm{No}$ nije baš tako jer je hipokloritna kiselina nespecifičan reagens, pa reagira praktički sa svim organskim i anorganskim tvarima. Stoga nije prikladno dezinfekcijsko sredstvo u prisustvu organske tvari, primjerice za dezinfekciju pčelinjeg saća. ${ }^{16}$

$\mathrm{HOCl}$ reagira prije svega s aminima: ${ }^{17}$

$$
\begin{aligned}
& \mathrm{RNH}_{2}+\mathrm{HOCl} \rightarrow \mathrm{RNHCl}+\mathrm{H}_{2} \mathrm{O} \\
& \mathrm{RNHCl}+\mathrm{HOCl} \rightarrow \mathrm{RNCl}_{2}+\mathrm{H}_{2} \mathrm{O} .
\end{aligned}
$$

Od produkta prve reakcije (10) mogu potom nastati, eliminacijom, imini:

$$
\mathrm{R}-\mathrm{CH}_{2}-\mathrm{NHCl} \rightarrow \mathrm{R}-\mathrm{CH}=\mathrm{NH}+\mathrm{HCl},
$$

koji potom adicijom vode daju aldehide:

$$
\mathrm{R}-\mathrm{CH}=\mathrm{NH}+\mathrm{H}_{2} \mathrm{O} \rightarrow \mathrm{R}-\mathrm{CH}=\mathrm{O}+\mathrm{NH}_{3} \text {. }
$$

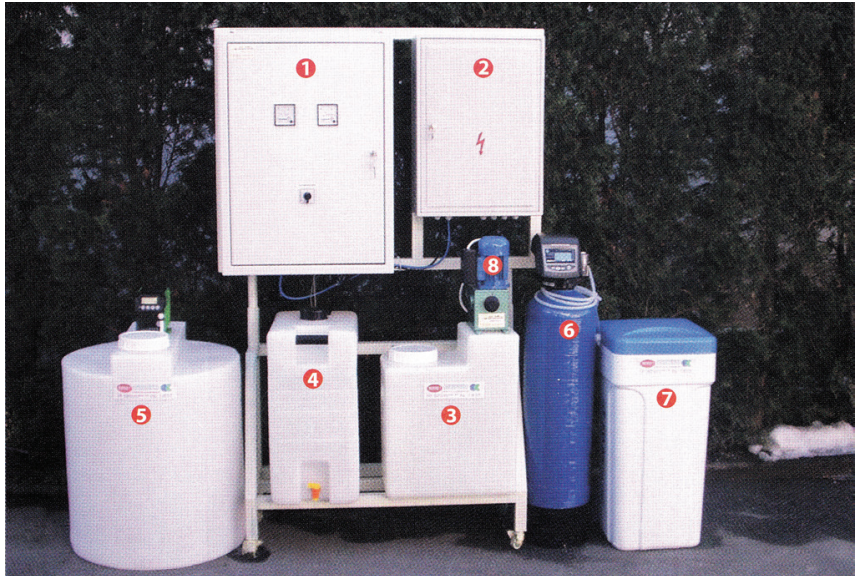

Slika 4 - Komercijalni uređaj OE-70 za proizvodnju razrijeđene klorne vode elektrolizom otopine natrijeva klorida (ref. 38): (1) elektroormar s transformatorom (220/24 V), (2) protočna ćelija za elektrolizu, (3) anolit (otopina $\mathrm{HOCl}$ ), (4) katolit (otopina $\mathrm{NaOH}$ ), (5) posuda za pripravu elektrolita (zasićene otopine $\mathrm{NaCl}$ ), (6) omekšivač vode (ionski izmjenjivač), (7) posuda za pripravu otopine $\mathrm{NaCl}$ za regeneraciju ionskog izmjenjivača, (8) crpka za doziranje.

Fig. 4 - Commercial system OE-70 for the production of diluted chlorine water by electrolysis of $\mathrm{NaCl}$ solution (Ref. 38); (1) electric devices, including 220/24 V transformer, (2) flowing electrolytic cell, (3) anolyte ( $\mathrm{HOCl}$ solution) tank, (4) catholyte ( $\mathrm{NaOH}$ solution) tank, (5) electrolyte ( $\mathrm{NaCl}$ solution) tank, (6) ion-exchanger, (7) tank with brine for regeneration of ion-exchanger, (8) pulse dozer.

Hipoklorasta kiselina adira se na dvostruku i trostruku vezu, a usto oksidira sulfidrilne skupine $(-\mathrm{SH})$ pri čemu nastaju disulfidni mostovi između molekula cisteina (slika 5). Ona također oksidira askorbinsku kiselinu i reducirani glutation ${ }^{18}$ te prostetičke skupine proteina koje sadrže željezo (hem i FeS). ${ }^{19}$ Sve to ukazuje na njezino baktericidno djelovanje, ali i na oštećenja molekula lipida, proteina i nukleinskih kiselina koja mogu nastati uslijed izlaganja hipokloritima, a napose hipoklorastoj kiselini.

Često se voli isticati, pogotovo u promidžbenim porukama proizvođača "superoksidirane vode" da je ona "ekološko sredstvo" jer ne sadržava alkohol, nije zapaljiva ni korozivna, da je neotrovna i ne izaziva iritacije te da je "100\% prirodna" (100 \% natural). ${ }^{20}$ Zbog niske koncentracije klora, posebice u obliku $\mathrm{Cl}_{2}$, doista se može smatrati neotrovnom, no specifikacija "100\% prirodna" ima (klimavi) temelj u činjenici da neutrofili (polimorfonuklearni neutrofilni leukociti) uništavaju mikrobe upravo hipoklorastom kiselinom. ${ }^{21}$ Riječ je o enzimu mieloperoksidazi (MPO) koji se nalazi na membrani stanica neutrofilnih leukocita. Taj je enzim ključan u sintetizi HOCl koju stanica izlučuje u izvanstanični prostor ili u svoj probavni (fagocitozni) mjehurić.

Kako u leukocitu nastaje $\mathrm{HOCl}$ ? Superoksidne ione $\left(\mathrm{O}_{2}{ }^{-}\right)$, nastale reakcijom NADPH i molekularnog kisika (posredovanjem NADPH-oksidaze):

$$
\mathrm{NADPH}+2 \mathrm{O}_{2} \rightarrow \mathrm{NADP}^{+}+\mathrm{H}^{+}+2{ }^{\cdot} \mathrm{O}_{2}{ }^{-},
$$




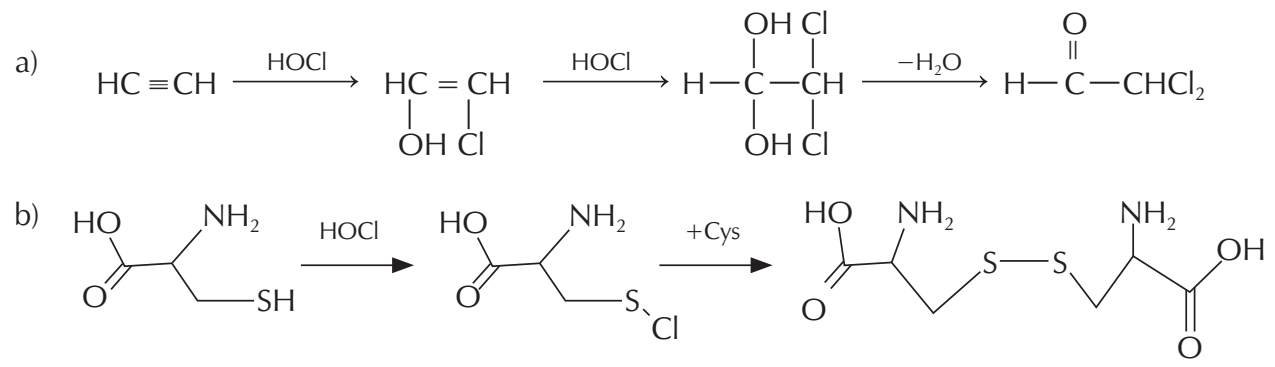

Slika 5 - Dvije karakteristične reakcije hipokloraste kiseline: (a) adicija na trostruku i dvostruku vezu i (b) oksidacija skupine - SH, na primjeru molekule cisteina (Cys)

Fig. 5 - Two characteristic reactions of hypochlorous acid; (a) addition to triple and double bond, (b) oxidation of $-\mathrm{SH}$ group, example of cysteine (Cys)

superoksid-dismutaza (SOD) prevodi u vodikov peroksid, koji potom drugi enzim, katalaza, disproporcionira na molekulski kisik i vodu. No dio nastalog $\mathrm{H}_{2} \mathrm{O}_{2}$ koristi mieloperoksidaza za oksidaciju klorida u hipoklorastu kiselinu. To je vrlo složen proces koji se, međutim, može sumarno opisati jednadžbom:

$$
\mathrm{H}_{2} \mathrm{O}_{2}+\mathrm{Cl}^{-} \rightarrow \mathrm{HOCl}+\mathrm{OH}^{-} .
$$

$\mathrm{HOCl}$ nastala djelovanjem MOP ne uništava samo bakterijske stanice nego oštećuje i stanice okolnog tkiva. ${ }^{22}$ Budući da oštećuje, uz druge biomolekule, i molekulu DNA, hipoklorasta kiselina je mutagena (genotoksična), pa stoga i potencijalno kancerogena. ${ }^{23,24}$ Upravo se tim mehanizmom djelovanja neutrofilnih leukocita objašnjava da dugotrajni upalni procesi mogu dovesti do pojave karcinoma (oksidacijski stres).

\section{Stabilnost otopine hipokloraste kiseline}

Klorna voda, u razrijeđenom obliku, paradoksalno je dezinfekcijsko sredstvo ili - može se i tako reći - vrlo neobičan proizvod kemijske industrije. Riječ je o dva stoljeća staroj tehnologiji, pa opet sasvim novoj. Elektroliza otopine $\mathrm{NaCl}$ poznata je od 1801. godine. Klor se naveliko rabi za dezinfekciju ("kloriranje") vode, ${ }^{25}$ a klorna voda, koncentracije $4-5 \mathrm{gl}^{-1}$ (Aqua chlorata, Aqua Chlori, Solutio Chlori) upotrebljavala se u medicini. Unatoč tome, nastala je potreba da se i samo ime klorne vode zaštiti (Medilox ${ }^{\circledR}$, Sterilox $\left.{ }^{\circledR}\right)$ te da se podnese patentna prijava u kojoj se precizno navode metode za njezinu prozvodnju te joj se specificira sastav i upotreba. ${ }^{26}$

Problem s klornom vodom koja se priređuje kao dezinfekcijsko sredstvo za širu upotrebu, za razliku od one koja se priređuje radi kloriranja vode, je da mora biti pakirana u prikladnu ambalažu te biti u njoj stabilna dulje vrijeme, više od šest mjeseci ${ }^{20}$ ili čak dvije godine. ${ }^{26}$ To je bilo vrlo teško postići jer je hipoklorasta kiselina vrlo reaktivna, pa stoga i nestabilna tvar. Prije svega "elektrokemijski aktivirana voda" mora biti proizvedena od čistih kemikalija, $\mathrm{NaCl}$ čistoće 99,9\% te vode pročišćene ionskom izmjenom i reverznom osmozom (membranskom filtracijom), kako bi bila čista i od anorganskih i od organskih nečistoća, a po- sebice od suspendiranih čestica $(<80$ ppm ukupnih nečistoća). ${ }^{26}$ Mora biti hermetički zatvorena u neprozirnoj i kemijski rezistentnoj (PET) ambalaži. I elektrode moraju, dakako, biti izrađene od čistog i kemijski rezistentnog materijala, posebice anoda (grafit, titanij).

Klor je fotokemijski reagens. $U$ plinovitom stanju, obasjan modrom svjetlošću ( $\lambda=450 \mathrm{~nm}$ ) razlaže se na atome (radikale) klora:

$$
\mathrm{Cl}_{2}(\mathrm{~g}) \stackrel{\text { hv }}{\longrightarrow} 2 \cdot \mathrm{Cl}(\mathrm{g}),
$$

koji potom mogu reagirati s vodikom, pri čemu uz eksploziju nastaje klorovodik (klorov praskarac). Vodik se može spajati s klorom i bez eksplozije ako u njemu gori, baš kao u zraku ili kisiku.

Slično kloru, i HOCl se raspada fotokemijski, no djelovanjem ultraljubičastog zračenja $(\lambda=254 \mathrm{~nm})$ :

$$
\mathrm{HOCl} \stackrel{h_{v}}{\longrightarrow} \cdot \mathrm{Cl}+\cdot \mathrm{OH},
$$

pri čemu nastaju vrlo reaktivni klorni $\left({ }^{\circ} \mathrm{Cl}\right)$ i hidroksilni $\left({ }^{\circ} \mathrm{OH}\right)$ radikali. ${ }^{27} \mathrm{Ti}$ radikali potom stupaju u mnoge reakcije, od kojih su možda najvažnije reakcije s molekulama hipokloraste kiseline:

$$
\begin{gathered}
\cdot \mathrm{OH}+\mathrm{HOCl} \rightarrow \mathrm{H}_{2} \mathrm{O}+{ }^{\cdot} \mathrm{OCl} \\
{ }^{\circ} \mathrm{Cl}+\mathrm{HOCl} \rightarrow \mathrm{HCl}+{ }^{\cdot} \mathrm{OCl} \\
2{ }^{\circ} \mathrm{OCl}+\mathrm{H}_{2} \mathrm{O} \rightarrow \mathrm{HCl}+\mathrm{HClO}_{3} .
\end{gathered}
$$

Posljedica fotokemijskog nastajanja radikala je da se $\mathrm{HOCl}$ priređena s neioniziranom vodom te izložena sunčevu svjetlu može posve raspasti već za dva sata (slika 6), ${ }^{28}$ pri čemu kao konačni produkt nastaje klorovodik i kisik:

$$
2 \mathrm{HOCl} \stackrel{h v}{\rightarrow} 2 \mathrm{HCl}+\mathrm{O}_{2} .
$$

Mjerenje vremena poluživota otopljene $\mathrm{HOCl}$ ukazalo je na velike razlike u djelovanju potencijalnih, kako organskih tako i anorganskih nečistoća. ${ }^{28}$ Poluživot klorne vode uz dodatak nitrita $\left(\mathrm{NO}_{2}{ }^{-}\right)$, sulfita $\left(\mathrm{SO}_{3}{ }^{-}\right)$, i fosfita $\left(\mathrm{PO}_{3}{ }^{2-}\right)$ te akorbinske kiseline, željezova(II) klorida i protamina kraći je od 10 min, uz dodatak CuS iznosi 30 min, a uz onečišćenje formaldehidom (metanalom) jedan dan. Stabilnost 


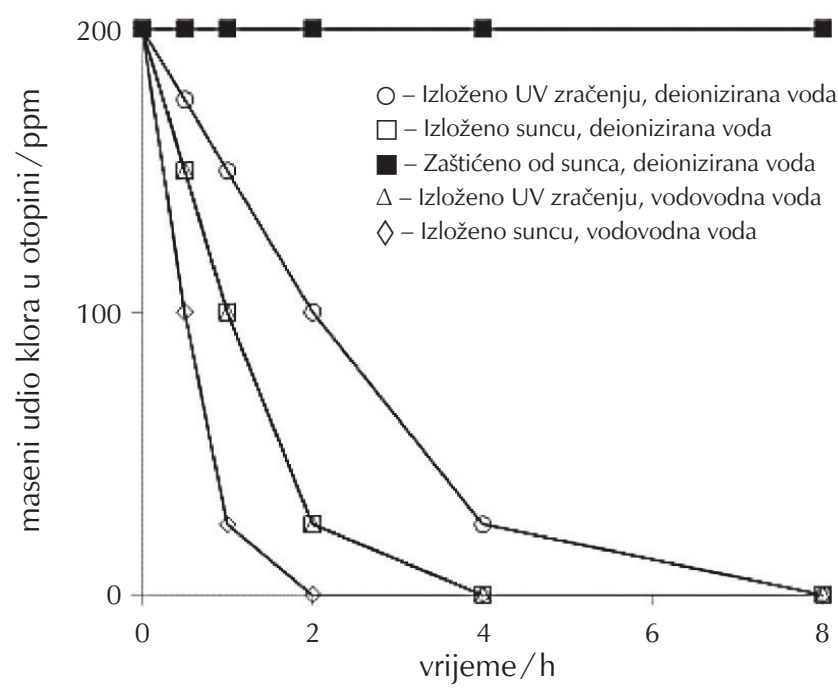

Slika 6 - Utjecaj čistoće vode i osvjetljenja na stabilnost razrijeđene klorne vode (ref. 28)

Fig. 6 - Influence of light and water purity on stability of diluted chlorine water (Ref. 28)

ovisi i o kiselosti: otopina s $\mathrm{pH}=8$ stabilnija je od otopine $\mathrm{s} \mathrm{pH}=6$. Zaluživanjem otopine poluživot joj se produljuje, ako je onečišćena glicinom ili albuminom od 1 na 2 h, a ako je onečišćena nitratima $\left(\mathrm{NaNO}_{3}, \mathrm{KNO}_{3}\right)$ od 2 na 7 dana. Stabilnost otopine se zaluživanjem najviše produljuje (od 10 min na 2 h) ako sadrži amonijev klorid.

Istraživanje utjecaja svjetlosti pokazalo je da otopina hipokloraste kiseline (Sterilox $\left.{ }^{\circledR}\right)$, ako se drži u mraku, može ostati stabilna 40 dana, dok se za to vrijeme ista otopina izložena svjetlosti potpuno raspadne. ${ }^{29}$ Pokazalo se istraživanjem utjecaja temperature i materijala u kojem se drži otopina da je staklo bolji material od polistirena, no da je ipak presudnija temperatura na kojoj se čuva otopina (4 ili $\left.20{ }^{\circ} \mathrm{C}\right) .{ }^{30} \mathrm{Od}$ materijala se ipak najboljim pokazao bijeli, neprozirni poli(etilen-tereftalat), PET, s dodatkom 2 - $3 \%$ $\mathrm{TiO}_{2}$, dok se pakiranje u polietilenske boce (PE, HDPE) pokazalo posve neprikladnim. ${ }^{26}$

\section{Zaključak}

Tema klorne vode s niskom koncentracijom aktivnog klora $\left(<200 \mathrm{mg}^{-1}\right)$ sasvim je prikladna da se uobliči u učenički istraživački miniprojekt. Razlog tome je što ta tema ujedinjuje praktički sve grane kemije (anorganska i organska kemija, fotokemijske i redoks-reakcije, ${ }^{31,32}$ reakcije slobodnih radikala, ${ }^{33}$ elektrokemija, kemijska kinetika i termodinamika), a usto povezuje kemiju s kemijskom tehnologijom (proizvodnja klora i klorne vode) te biologijom i zdravstvenim odgojem ( $\mathrm{HOCl}$ kao dezinfekcijsko sredstvo i metabolit). Može također poslužiti kao primjer kemijske ravnoteže i reaktivnosti, na što upućuje naslov ovoga rada, ali biti i nadopuna nastavne jedinice o halogenim elementima (npr. učenički referat).

Proizvodnja klorne vode elektrolizom otopine $\mathrm{NaCl}$ vrlo je jednostavna - naravno, ako se ne inzistira na čistoći i trajnosti pripravka - te se može lako izvesti u školskom laboratoriju ili na satu kemije. Riječ je o bezopasnom pokusu jer se radi s niskim naponima struje, s nekorozivnim i neotrovnim elektrolitom, dok se produkti elektrolize $(\mathrm{NaOH}$, $\mathrm{HOCl}, \mathrm{H}_{2}$ ), iako su sami po sebi opasni (korozivi i zapaljivi), proizvode u miligramskim količinama, pa praktički ne predstavljaju opasnost ni za koga (maksimalno dopuštena koncentracija klora u zraku je $2 \mathrm{mg} \mathrm{m}^{-3}$ ).

Istraživački miniprojekt mogao bi se usredotočiti na sljedeće postupke:

1.) proizvodnja $\mathrm{HOCl}$ niske koncentracije (50 - $100 \mathrm{mg} \mathrm{l}^{-1}$ ) elekrolizom vodene otopine $\mathrm{NaCl}$;

2.) mjerenje $\mathrm{pH}$ dobivene otopine $\mathrm{u}$ anodnom $(\mathrm{HOCl}) \mathrm{i}$ katodnom $(\mathrm{NaOH})$ prostoru;

3.) mjerenje koncentracije aktivnog klora elektrokemijskim, volumetrijskim i spektroskopskim metodama; ${ }^{9}$

4.) istraživanje utjecaja svjetla na stabilnost otopine;

5.) ispitivanje baktericidnih (dezinfekcijskih) svojstava klorne otopine (to bi trebalo provesti u suradnji s profesorom biologije);

6.) ispitivanje utjecaja klorne vode na trajnost rezanog cvijeća u vazi. Pokazalo se, naime, da rezano cvijeće može ostati svježe 14 - 30 dana ako se obična voda zamijeni kloriranom $^{26}$ (za taj pokus bolje se poslužiti komercijalnim pripravkom);

7.) pokus s "tajnim pismom": piše se otopinom kalijeva jodida po podlozi koja sadržava škrob (krumpir, tjestenina, žganci, puding, ali i papirnata maramica), a razvija klornom vodom.

Navedene pokuse treba popratiti prikladnim teorijskim proračunima, iz kojih se može mnogo naučiti ("stehiometrijski zadaci sa smislom" ${ }^{34}$ ), pa i ako se pokusi ne izvedu. Može se, primjerice, izračunati sastav otopine u katodnom i anodnom prostoru ( $\mathrm{HOCl}, \mathrm{NaOH}, \mathrm{NaCl})$ iz zadanog trajanja elektrolize, jakosti struje i početne koncentracije $\mathrm{NaCl}$. Iz toga se opet može izračunati vrijednost pH dobivene lužine. Sve u svemu, ima mnogo tema za inventivnog nastavnika i pitanja za nadobudnog učenika.

\section{Literatura \\ References}

1. D. Grdenić, Povijest kemije, Novi Liber i Školska knjiga, Zagreb, 2001., str. 479

2. J. Dalton, A New System of Chemical Philosophy. Part II., London and Manchester, 1808., p. 297-309.

3. H. Davy, Researches on the oxymuriatic acid, its nature and combinations; and on the elements of the muriatic acid. With some experiments on sulphur and phosphorus, made in the laboratory of the Royal Institution, Philosoph. Trans. 100 (1810) 231-257, doi: https://doi.org/10.1098/ rstl.1810.0016.

4. H. Davy, The Bakerian lecture. On some of the combinations of oxymuriatic gas and oxygene, and on the chemical relations of these principles, to inflammable bodies, Philosoph. Trans. 101 (1811) 1-35, doi: https://doi.org/10.1098/ rstl.1811.0001.

5. History of chlor-alkali industry, p. 17-36, https://beck- 
assets.blob.core.windows.net/product/readingsample/692761/9780306486234_excerpt_001.pdf.

6. J. C. Morris, The acid ionization constant of $\mathrm{HOCl}$ from 5 to $35{ }^{\circ} \mathrm{C}$, J. Phys. Chem. 70 (12) (1966) 3798-3805, doi: https://doi.org/10.1021/j100884a007.

7. E. M. Aleta, P. V. Roberts, Henry constant of molecular chlorine in aqueous solution, J. Chem. Eng. Data 31 (1986) 5153, doi: https://doi.org/10.1021/je00043a017.

8. M. A. Alkan, M. Oktay, M. M. Kocakerim, M. Capur, Solubility of chlorine in aqueous hydrochloric acid solutions, J. Hazard. Mater. A119 (2005) 13-18, doi: https://doi.org/10.1016/j. jhazmat.2004.11.001.

9. M. Eryilmaz, I. M. Palabiyik, Hypochlorous acid - analytical methods and antimicrobial activity, Trop. J. Pharm. Res. 12(1) (2013) 123-126, doi: https://doi.org/10.4314/tjpr.v12i1.20.

10. M. S. Block, B. G. Rowan, Hypochlorous acid: a review, J. Oral. Maxillofac. Surg. 78 (2020) 1461-1466, doi: https:// doi.org/10.1016/j.jams.2020.06.029.

11. R. M. Thorn, S. W. Lee, G. M. Robinson, J. Greenman, D. M. Reynolds, Electrochemically activated solutions: Evidence for antimicrobial efficiency and application in healthcare environments, Eur. J. Clin. Microbiol. Infect. Dis. 31 (2012) 641-653, doi: https://doi.org/10.1007/s10096-011-1369-9.

12. B. V. Sarada, R. Vijaj, R. Johnson, N. Rao, G. Padmanabham, Fight against COVID-19: ACRI's technologies for disinfection, Trans. Ind. Nat. Acad. Sci. 5 (2020) 349-345, doi: https://doi.org./10.1007/s41403-020-00153-3.

13. T. Y. Choi, W. B. Kim, Bactericidal effect of disinfectant a super-oxidized water, Medilox ${ }^{\circledR}$, Korean J. Nosocomial Infect. Control 3(1) (1998) 1-6.

14. T. Staničić, Nova saznanja o natrijevu hipokloritu, Acta Stomatol. Croat. 16 (1) (1982) 67-71, url: https://hrcak.srce.hr/ file/155247.

15. I. Miletić, A. Knežević, I. Anić, M. Osmak. J. Šutalo, Z. Blažić-Potočki, Citotoksičnost natrij-hipoklorita na kulturama stanica, Acta Stomatol. Croat. 33(1) (1999) 25-29.

16. I. Ohashi, K. Kato, M. Okamoto, S. Kobayashi, D. Takamatsu, Microbicidal effects of slightly acidic hypochlorous acid water and weakly acidified chlorous acid water on foulbrood pathogens, J. Vet. Med. Sci. 82 (3) (2020) 261-271, doi: https://doi. org./10.1292/jvms.19-0531.

17. C. L. Hawkins, D. I. Pattison, M. J. Davies, Hypochlorite-induced oxidation of amino acids, peptides and proteins. Review article, Amino acids 25 (2003) 259-274, doi: https:// doi. org./10.1007/s00726-003-0016-x.

18. L. K. Folkes, L. P. Candeias, P. Wardman, Kinetics and mechanism of hypochlorous acid reaction, Arch. Biochem. Bipohys. 323 (1995) 120-126, doi: https://doi.org/10.1006/ abbi.1995.0017.

19. J. M. Albrich, C. A. McCathy, J. K. Hurst, Biological reactivity of hypochlorous acid: Implication for microbicidal mechanisms of leucocyte myeloperoxidase, Proc. Natl. Acad. Sci. USA 78 (1981) 210-214, doi: https://doi.org/10.1073/ pnas.78.1.210.

20. Technical Specification for Neutral Anolyte (HOCl) Generator, www.tiaano.com/marketing@tiaano.com.

21. A. J. Kettle, C. C. Winterbourn, Myeloperoxidase: a key regulator of neutrophil oxidant production, Redox Rep. 3 (1) (1997) 3-15, doi: https://doi.org/10.1080/13510002.1997. 11747085.

22. J. M. Pullar, M. C. M. Vissers, C. C. Winterbourn, Living with a killer: the effects of hypochlorous acid on mammalian cells, IUBMB Life 50 (2000) 259-266, doi: https://doi. org/10.1080/713803731.

23. C. L. Hawkins, M. J. Davies, Hypochlorite-induced damage to DNA, RNA, and polynucleotides: Formation of chloramines and nitrogen-centered radicals, Chem. Res. Toxicol. 15 (2002) 83-92, doi: https://doi.org./10.1021/tx015548d.

24. N. Güngör, A. M. Knaapen, A. Munnia, M. Peluso, G. R. Haenen, R. K. Chiu, R. W. L. Godschalk, F. J. van Schooten, Genotoxic effects of neutrophils and hypochlorous acid, Mutagenesis 25 (2) (2010) 149-154, doi: https://doi.org./10.1093/ mutage/gep053.

25. N. Zečević, Poboljšanje rada sustava bistrenja sirove vode akumulacijskog jezera Pakra, Kem. Ind. 60(10) (2011) 497503, url: https://hrcak.srce.hr/72063.

26. P. Robertson, JR., P. Theruviparampil, L. Balley, Method for producing shelf stable hypochlorous acid solutions, Patent Application Publication, Pub. No.: US 2015/0119245 A1, Apr. 30, 2015.

27. Y. Feng, D. W. Smith, J. R. Bolton, Photolysis of aqueous free chlorine species $\left(\mathrm{HOCl}\right.$ and $\left.\mathrm{OCl}^{-}\right)$with $254 \mathrm{~nm}$ ultraviolet light, J. Environ. Eng. Sci. 6 (2007) 277-284, doi: https://doi. org./10.1139/S06-052.

28. M. Ishihara, K. Murakami, K. Fukuda, S. Nakamura, M. Kuwabara, H. Hattori, M. Fujita, T. Kiyosawa, H. Yokoe, Stability of weakly acidic hypochlorous acid solution with microbicidal activity, Biocontrol Sci. 22 (4) (2017) 223-227, doi: https://doi.org./10.4265/bio.22.223.

29. G. Rossi-Fedele, E. J. Dogramaci, L. Steier, J. A. P. de Figueiredo, Some factors influencing the stability of Sterilox ${ }^{\circledR}$, a super-oxidized water, Brit. Dent. J. 210 (2011) E23, 1-3, doi: https://doi.org./10.1038/sj.bdj.2011.143.

30. G. Robinson, R. Thorn, D. Reynolds, The effect of long-term storage on the physiochemical and bactericidal properties of electrochemically activated solutions, Int. J. Mol. Sci. 14 (2013) 457-469, doi: https://doi.org./10.3390/ ijms14010457.

31. N. Raos, Što nam kazuje oksidacijski broj, Kem. Ind. 65 (9-10) (2016) 515-518, doi: https://doi.org./10.15255/ KUI.2016.020.

32. N. Raos, Učenje redoks-reakcija iz željezno-sumporne teorije o porijeklu života, Kem. Ind. 67 (7-8) (2018) 325-328, doi: https://doi.org./10.15255/KUI.2016.033.

33. K. Molčanov, Dva školska sata kemije (slobodnih) radikala, Kem. Ind. 66 (11-12) (2017) 667-674, https://doi. org./10.15255/KUI.2017.029.

34. N. Raos, Stehiometrija sa smislom, Kem. Ind. 66 (9-10) 529 533, doi: https://doi.org./10.15255/KUI.2017.002.

35. M. C. Robson, W. G. Payne, F. Ko, M. Mentis, G. Donati, S. M. Schafii, S. Culverhouse, L. Wang, B. Khosrovi, R. Najafi, D. M. Cooper, M. Bassiri, Hypochlorous acid as a potential wound care agent. Part II. Stabilized hypochlorous acid: Its role in decreasing tissue bacterial bioburden and overcoming the inhibition of infection on wound healing, J. Burng Wounds 6 (2006) 80-90, url: https://www.researchgate.net/publication/6339980.

36. US Patent for Physiologically balanced, ionized, acidic solution and methodology for use in wound healing (Patent \# 7,393,522 issued July 1, 2008), https://patents.justia.com/ patent/7393522.

37. W. A. Rutala, D. J. Weber, New disinfection and sterilization methods, Emerg. Infect. Dis. 7 (2) (2001) 348-353, doi: https://doi.org/10.3201/eid0702.010241.

38. OKSIEKO uređaj tip OE-70, Obrt Bovje, Zagreb, http:// www.obrtnici-zagreb.hr/novosti/ obrt-bovje-proizvođač-uređaja-za-dobivanje-dezificijensa-oksieko. 


\section{SUMMARY}

\section{Chlorine in Water - An Example of Chemical Equilibria and Reactivity Nenad Raos}

Chlorine water is not, simply, chlorine gas dissolved in water, but a complex solution of chlorine, $\mathrm{Cl}_{2}(\mathrm{aq})$, hydrochloric $(\mathrm{HCl})$, and hypochlorous acid $(\mathrm{HOCl})$, containing also $\mathrm{Cl}_{3}{ }^{-}$ions as well as $\mathrm{NaCl}$ from original electrolyte. All of these components are in mutual equilibria. In this paper a short history of chlorine chemistry and technology is presented, as well as reversible and free-radical reactions in its aqueous solution. Properties of $\mathrm{HOCl}$ as a disinfectant and its physiological effects are also discussed. Diluted, 50-100 ppm HOCl solutions, named "electrochemically activated water" (ECA), or similar, have recently become popular disinfectants. Despite the advantage of its simple preparation, by electrolysis of $\mathrm{NaCl}$ solutions, ECA is very unstable, so the utmost care must be paid to its preparation and protection from light. Diluted chlorine water, if properly prepared and stored, could be stable for months.

\section{Keywords}

Chemistry education, history of chemistry and chemical technology, hypochlorous acid, disinfectants, reactions of chlorine

Institute for Medical Research

\section{BOVJE-PROMET d.o.o. proizvođač uređaja OKSIEKO za dobivanje dezinficijensa BOVJE SEPT}

\section{Nove}

OKSIEKO

Uređaj za proizvodnju BOVJE SEPT

Kapacitet: $72 \mathrm{~L} / \mathrm{h}$ anolita (koncentrata) Dezinfekcijski kapacitet: $72 \mathrm{~m}^{3} / \mathrm{h}$ 1. Elektroormar s transformatorom 220/24 V

2. Reaktor (elektrokemijska čelija)

3. Anolit (OKSIEKO koncentrat)

4. Katolit $(\mathrm{NaOH}$ i NaCl)

5. Sirovina: tabletirana sol $(\mathrm{NaCl})$

6. Omekšivač vode

7. $\mathrm{NaCl}$ za omekšavanje vode

8. Dozirna crpka za OKSIEKO

Program OKSIEKO

- Isporuka, montaža i održavanje uređaja za proizvodnju dezinficijensa OKSIEKO.

- Prilagodba uređaja situaciji na terenu.

- Dobivanje hipokloraste kiseline u širokom rasponu količina i koncentracija.

- Posebna rješenja prilagođena potrebama korisnika.

(npr. doziranje dezinficijensa bez korištenja električne energije)

\section{USLUGE}

- Sustavi za filtriranje vode - prirodni tretman bez kemikalija.

Naši filterski sustavi rade prema prirodnom principu. Vodu prozračujemo prirodno, dodajući joj kisik.

Tako uzrokujemo oksidaciju željeza, amonijaka i mangana. Intenzivna ventilacija uklanja mirise, a suspendirana tvar se filtrira kroz filtrirajući materijal.

- Servis i adaptaciju svih tipova uređaja za pripremu pitke vode i kondicioniranje bazenske vode.

- Ugradnja sustava za uklanjanje klora iz atmosfere u slučajevima akcidenata.
"BOVJE PROMET" d.o.o. za trgovinu, graditeljstvo i usluge održavanja Dolenec 47, BUŠEVEC 10417

Fax: 016219215

Mob: 0911805952

E-pošta: bovje@zg.t-com.hr

\section{BOVJE SEPT}

Dezinficijens bez kemikalija

- Vodena otopina hipokloritne kiseline koncentracije 50-7.000 ppm - Dezinficijens dobiven elektrolizom vodene otopine natrijevog klorida. - Vrsta biocidnog pripravka 1,2,3 i 4.

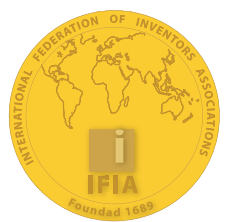

Nagrada IFIA 2020 